\title{
Catchment scale tracer testing from karstic features in a porous limestone.
}

\author{
L. Maurice ${ }^{a b}$, T.C. Atkinson ${ }^{b}$, A.T. Williams ${ }^{a}$, J.A. Barker ${ }^{c}$ and A.R. Farrant ${ }^{d}$ \\ ${ }^{a}$ British Geological Survey, Maclean Building, Wallingford, Oxfordshire, OX10 8BB, UK \\ ${ }^{b}$ University College London, Department of Earth Sciences, Gower Street, London WC1E 6BT, UK \\ ${ }^{\mathrm{C}}$ School of Civil Engineering and the Environment, University of Southampton, Highfield, Southampton, SO17 1BJ, \\ UK \\ ${ }^{d}$ British Geological Survey, Kingsley Dunham Centre, Keyworth, NG12 5GG, UK
}

Corresponding author: Louise Maurice. Email: loma@bgs.ac.uk. Tel: +44 (0)1491838800. Fax: + 44 (0)1491 692345.

\begin{abstract}
Tracer testing was undertaken from sinking streams feeding the Chalk, a porous limestone aquifer characterised by frequent small-scale surface karst features. The objective was to investigate the nature and extent of sub-surface karstic development in the aquifer. Previous tracer testing has demonstrated rapid flow combined with low attenuation of tracer. In this study, at two sites rapid groundwater flow was combined with very high attenuation and at two other sites no tracer was detected at springs within the likely catchment area of the stream sinks tested, suggesting that tracer was totally attenuated along the flowpath. It is proposed that the networks beneath stream sinks in the Chalk and other mildly karstic aquifers distribute recharge into multiple enlarged fractures that divide and become smaller at each division whereas the networks around springs have a predominantly tributary topology that concentrates flow into a few relatively large cavities, a morphology with similarities to that of the early stages of karstification. Tracer attenuation is controlled by the degree to which the two networks are directly connected. In the first state, there is no direct linkage and flow between the two networks is via primary fractures in which tracer attenuation is extreme. The second state is at a percolation threshold in which a single direct link joins the two networks. A very small proportion of tracer reaches the spring rapidly but overall attenuation is very high. In the third state, the recharge and discharge networks are integrated therefore a large fraction of tracer reaches the spring and peak concentrations are relatively high. Despite the large number of stream sinks that recharge the Chalk aquifer, these results suggest that sub-surface conduit development may not always be continuous, with flow down smaller fissures and fractures causing high attenuation of solutes and particulates providing a degree of protection to groundwater outlets that is not seen in more highly karstic aquifers. Bacteriophage tracers that can be detected at very large dilutions $\left(10^{15}\right)$ are recommended for investigating groundwater pathways where attenuation may be high.
\end{abstract}

Keywords: Tracer testing; Karst; Groundwater protection; Chalk.

\section{Introduction}

The Chalk is the most important water supply aquifer in England and protecting the quality of its groundwater requires an effective understanding of its hydrogeology. This paper deals with recharge from sinking streams - referred to as swallow holes in early literature (Long, 1842; Prestwich, 1854) - that have long been recognised as presenting a risk of contamination to water supplies (e.g. Whitaker, 1886). The Chalk is a porous fractured limestone that exhibits small-scale karstic features at the surface - sinking streams and dolines, plus an extensive dry valley network. Subsurface karst is also developed to some degree (Banks et al., 1995; MacDonald et al., 1998; Maurice et al., 2006; Worthington and Ford, 2009) but the influence this has on groundwater flow and contaminant transport remains poorly understood. It is not even certain whether an occurrence of dolines and sinking streams is a reliable 
indication that karst channels exist in the aquifer beneath them, nor how far such channels might extend where they are present. In this paper we describe tracer tests from sinking streams in the Pang and Lambourn catchments in southern

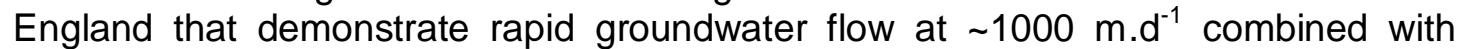
attenuation of tracer concentration that is extremely variable from site to site. The tracer results throw light on the networks of karst channels and enlarged fractures into which sinking streams feed their recharge, and on connections with the network of primary fractures that pervades the whole aquifer. Testing at some sinking streams showed rapid flow combined with low attenuation over distances of several kilometres, resulting in a substantial fraction of the tracer emerging with relatively high concentrations at springs. This situation presents a clear hazard to water quality if contaminants enter the aquifer via the sinking stream. Previous tracer tests on sinking streams in the Chalk have all belonged to this type. In other cases the tracers travelled fast but were attenuated to concentrations only just greater than the detectable threshold. In this situation the hazard would be much diminished, because although a tiny proportion of contaminant would travel rapidly its concentration at springs and boreholes would be very low and perhaps harmless.

\section{Background}

In the Pang and Lambourn catchments in Southern England many stream sinks are concentrated around the edge of the Palaeogene outcrop (Maurice et al. (2006); Figs. 1 and 2). Elsewhere in the English Chalk, shallow sediment-filled solution pipes or hollows, dolines and small stream sinks occur where there is a thin cover of Palaeogene deposits or clay-with-flints (Wooldridge \& Kirkaldy, 1937; Sperling et al., 1977; Lamont-Black \& Mortimore, 1999; Farrant, 2001). The Palaeogene comprises gravels, sands, silts and clays which produce slightly acidic soils. Sinking streams occur where the deposits are thin and composed of sands and gravels, allowing chemically aggressive infiltration to dissolve the underlying Chalk. It is likely that the very high density of stream sinks mapped in the Pang-Lambourn catchments also occurs in other areas where chalk is overlain by thin Palaeogene deposits or other deposits that produce acidic soils. In fully karstic aquifers, such as the limestones of Carboniferous age in the UK, sinking streams usually feed underground conduit systems in which groundwater flow is rapid and contaminant attenuation is low (e.g. Atkinson, 1977; Stanton \& Smart, 1981). Springs and boreholes that derive their flow from conduits are very vulnerable to contamination introduced from sinking streams, but it is not known how common conduits are in the English Chalk. At least one outbreak of Cryptosporidium has been connected to water supplies from a chalk source (Foster, 2000) and faecal bacteria and viruses are more common in boreholes located near the Palaeogene, as is the presence of suspended sediment following heavy rain (MacDonald et al., 1998). Most faecal bacteria survive for only about 10 days in groundwater (Foster, 2000), so water sources will be most vulnerable to bacterial contamination if groundwater flow is rapid and residence times are short. However, Cryptosporidium and many viruses may have longer viability in groundwater (Foster, 2000). Recharge from sinking streams has the potential to introduce a wide variety of chemical and biological contaminants into chalk groundwater and drinking water supplies, given the ease with which surface water can be accidentally contaminated by septic tank overflows or runoff from roads, farmyards, pasture and arable land.

Price (1987) discusses the relative contributions made to chalk permeability and transmissivity by matrix porosity, the primary fracture network, and 'secondary' fractures that have been widened by solution. The porosity of the rock matrix is substantial, $30-50 \%$, but its permeability is so low that pore water within the matrix can be regarded as immobile over the timescales involved in tracer tests. Primary fractures generally have apertures of less than $0.001 \mathrm{~m}$ and form a network that 
pervades the entire aquifer. Enlarged 'secondary' fractures (or fissures) are commonly observed in boreholes, but the lateral extent of such dissolutional features is uncertain. More circular shaped conduits and tubules from $\sim 1$ to $\sim 10 \mathrm{~cm}$ in diameter were described at outcrops by Lamont-Black and Mortimore (1999), and examples have been intercepted by boreholes, but their linear extent within the saturated zone and their role in channelling groundwater flow over long distances both remain largely unknown. Very few karst caves large enough to enter are known from the English Chalk. There is a cave more than $350 \mathrm{~m}$ long exposed in sea cliffs in the Beachy Head area, and there are shorter caves at Seven Sisters in Kent (Reeve, 1977; Lowe, 1992), and at Beer in Devon (Procter, 1984). Bradshaw et al. (1991) report several small caves beneath stream sinks at Water End in Hertfordshire (TL 23 04), Lower Ensden in Kent (TR 07 56), and Warren Row in Berkshire (SU 81 80). There are also reports of caves up to $60 \mathrm{~m}$ long that were intersected by wells at four sites in Kent but are no longer accessible (Warwick, 1962; Bradshaw et al., 1991). More substantial cave networks have been described in Northern Ireland (Barnes, 1999), and geomorphological karst development in the French Chalk (solution features and caves) appears to be much more significant than in England (Rodet, 1991; Rodet et al., 2009).

\section{Previous tracer tests from sinking streams in Chalk}

Codrington (1864), Harold (1937), Atkinson \& Smith (1974), Rodet (1991), Banks et al. (1995), Barnes (1999), Massei et al. (2002, 2006) and Maurice et al. (2006) all report tracer tests on sinking streams in chalk with results that are summarised in Table 1.

The earliest water tracing in the English Chalk was by Codrington (1864) who introduced dye into a stream sink in Wiltshire and reported its visible reappearance at a spring several kilometres away. Few details are given but the visible recovery suggests that attenuation was low. Harold (1937) reported a series of tests in which fluorescein dye was injected into a sinking stream at South Mimms, Hertfordshire and produced visible coloration at seven spring and borehole sites between 8 and $20 \mathrm{~km}$ from the injection, indicating a lateral spread of $6 \mathrm{~km}$. Velocities (based on first detections at the various sites) were 2.7 to $5.2 \mathrm{~km} \cdot \mathrm{d}^{-1}$ and the visible coloration implies relatively low attenuation, although amounts injected were very large. The first attempt at quantitative mass balance was by Atkinson \& Smith (1974) who found a rapid groundwater velocity of 2 to $2.6 \mathrm{~km} . \mathrm{d}^{-1}$ combined with low attenuation $(70 \%$ tracer recovery) along a $5.8 \mathrm{~km}$ pathway through confined chalk in Hampshire. Atkinson \& Smith (1974) envisaged the rapid flow as taking place along a cylindrical conduit with an estimated diameter of $0.74 \mathrm{~m}$, but Price (1987) demonstrated that a single horizontal fissure with $4.5 \mathrm{~mm}$ aperture would fit the observed data equally well.

Tracer tests on three sinking streams within the Pang and Lambourn catchments were previously published (Table 1). Banks et al. (1995) describe rapid flow between two sinking streams and the Blue Pool spring which discharges into the River Pang (Fig.1). A breakthrough curve was published but tracer recovery is unknown as the injection quantity is uncertain. Banks et al. (1995) deduced that transport could have taken place along a fissure with a constant 5 to $6 \mathrm{~mm}$ aperture, although like Price (1987) they emphasised that this was merely indicative and not a precise estimate of shape or size of the real cavities. Maurice et al. (2006) described two tests made with fluorescein from a sinking stream at Smithcroft Copse, near the two sites tested by Banks et al. (1995). Velocities were 4.7 and $5.1 \mathrm{~km} \cdot \mathrm{d}^{-1}$ and $22 \%$ and $25 \%$ of tracer was recovered. 
Tracer tests have also been conducted on sinking streams in the Chalk in Northern Ireland and in Normandy, France where there are differences in lithology and karst is more obvious than in the English Chalk. Groundwater velocities from nine sinking streams in Northern Ireland ranged from 0.5 to $2.8 \mathrm{~km} . \mathrm{d}^{-1}$ and tracer recoveries were 52 to $94 \%$ (Barnes, 1999). In the Bebec-Hannetot karst system in the Seine valley, Normandy, repeated tests showed velocities of 1.8 to $3 \mathrm{~km} . \mathrm{d}^{-1}$ and tracer recoveries greater than $90 \%$ (Massei et al., 2002, 2006). Many other tracer tests have been carried out in the French Chalk and indicate velocities of $\sim 4 \mathrm{~km} \cdot \mathrm{d}^{-1}$ over distances of up to $14 \mathrm{~km}$ (Rodet, 1991).

Previous tracer tests from sinking streams in the English Chalk have displayed a combination of rapid groundwater flow with generally low attenuation of the tracer, a style of transport that is also found in highly karstic aquifers. In the remainder of this paper we describe new tracer tests on sinking streams that provide a more complex picture in which rapid flow was combined with very high attenuation, including cases with complete losses of dye or bacteriophage.

\section{The study area}

The new tests were carried out in the catchments of the Rivers Pang and Lambourn (Figs.1 \& 2). The catchments rise to a maximum elevation of $\sim 270 \mathrm{~m}$ above Ordnance Datum and have an annual rainfall of $\sim 700 \mathrm{~mm} / \mathrm{year}$ and evapotranspiration rates of $\sim 500 \mathrm{~mm} /$ year (Wheater et al., 2006). The catchments are predominantly underlain by Chalk except in their lower reaches where the Chalk is overlain by Palaeogene deposits, and the stratal dip is $1-2^{0}$ to the South-South-East. Sinking streams are concentrated along the Palaeogene/Chalk boundary where concentrations of dolines also occur as well as a dry valley network (Maurice et al., 2006). The Blue Pool spring complex is the largest concentrated discharge of groundwater to the River Pang (Fig. 1). The discharge at the Blue Pool is fairly constant compared to classic karst springs which often have variable discharges. Flow data were collected at the Blue Pool on 15 occasions between 1976 and 1988 (Banks personal communication, 2007). Discharge varied between $150{\mathrm{~L} . \mathrm{s}^{-1}}^{-1}$

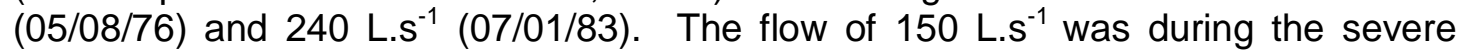
summer drought of 1976 and the data suggest that the Blue Pool generally maintains a flow of 180-200 L.s ${ }^{-1}$ during summer. The contour pattern of groundwater levels suggests that the Blue Pool derives its water from the northwest. However the tracer tests from Holly Lane and Tylers Lane reported by Banks et al. (1995) showed that part of the catchment lay due west of the spring, and this was confirmed by the two tests from Smithcroft Copse described by Maurice et al. (2006). In the present study, the Smithcroft Copse sink was tested for a third time and two new sites, Miram's Copse and Frilsham stream sinks, were chosen to investigate the range of directions from which the Blue Pool derives its water.

To test whether rapid groundwater flow occurs within the Lambourn catchment, two sinking streams were selected on a Palaeogene-capped ridge that lies to the east of the Winterbourne (Fig. 2) that occupies the lower part of a dry valley system. Close to its junction with the Lambourn are two groups of springs where the natural flows have been augmented by boreholes that overflow with groundwater. The Bagnor spring is adjacent to the Winterbourne whereas the Jannaways spring and borehole feed an artificial pond at a slightly higher elevation about $100 \mathrm{~m}$ to the west. The seasonal variability in flow at these springs is not known. However, the flows at Bagnor and Jannaways springs was estimated to be about 25 L.s-1 (in each spring) during the tracer testing (which was during a period of high groundwater levels), and substantial changes in flows were not observed during the tracer test. The sinking streams chosen were at Cromwells and Honeybottom (Fig. 2). At Cromwells a substantial stream sinks at the end of a blind valley about $10 \mathrm{~m}$ deep. The 
Honeybottom sink is much smaller, and is one of a series of dolines along the Palaeogene/Chalk boundary that accepts a very small flow of groundwater from the Palaeogene augmented by local runoff.

\section{Tracer methods}

Tracer tests were performed in four stages over the period 2004-2006. The optical brightener Photine CU was used at Miram's Copse stream sink in the first stage in 2004. Two bacteriophage tracer were used at Cromwells and Honeybottom stream sinks in the second stage in 2005, and at Miram's Copse and Frilsham stream sinks during the third stage in 2006. A third bacteriophage was used alongside several dyes at Smithcroft Copse stream sink in the fourth stage in 2006. During summer and during dry periods in winter the stream sinks are dry. Tracer testing was therefore carried out in winter during wet periods when the stream sinks were flowing and therefore the different tests were carried out under similar hydrological conditions. Flow was gauged regularly by current meter at the Blue Pool during all tracer tests but there was little variability (192-209 L. $\left.{ }^{-1}\right)$, and flow at Bagnor springs was estimated visually.

\subsection{Photine CU}

Photine CU was used at Miram's Copse stream sink. Six separate batches of the manufacturer's $20 \%$ solution were added to this sink over a period of seven months in 2004, increasing in steps from $125 \mathrm{ml}$ in the first batch to $5000 \mathrm{ml}$ in the last. The dye was monitored using the method of Smart (1976). Cotton wool detectors were placed at 13 spring, borehole and river sites shown in Fig. 1 and changed every $1-3$ days. Monitoring began four weeks before the first tracer injection and continued for six weeks after the last. Following retrieval from the field, each detector was rinsed with a jet of clean water and visually compared with a set of standard positive detectors under ultra-violet light to ascertain the presence of dye. There was no detectable tracer on any of the 447 detectors examined.

\subsection{Other dyes}

Fluorescein and other dyes were analysed in water samples by standard fluorometric methods (Käss, 1998) and also monitored continuously using field fluorometers. Maurice (2009) described the procedures in full.

\subsection{Bacteriophages}

Two single strains of bacteriophage were used, one having the bacterium Serratia marcescens as its host, the other Enterobacter cloacae. A specialist laboratory (CREH Analytical, Leeds, UK) prepared 1-litre solutions with concentrations of $2 \times 10^{12}$ pfu. $\mathrm{ml}^{-1}$ (plaque-forming units per $\mathrm{ml}$ ) and also performed the analyses of water samples. These were collected by hand and/or by automatic sampler at each site monitored, stored in cool boxes at about $5{ }^{\circ} \mathrm{C}$ and returned to the laboratory within a few days. They were analysed by covering a plate culture of the host bacterium with a thin film of water, incubating it for 24 hours and examining the plate for 'plaques', small areas in which there was a lysis (die-off) of the host bacterium (for illustration see Käss, 1998, Plates 7 \& 8). Two variations of this basic procedure were used. The first was to inoculate the plate directly using a small volume of the sample, normally $1 \mathrm{ml}$ but $0.1 \mathrm{ml}$ for samples that might have contained very high concentrations of bacteriophage. Results from this test were reported in pfu. $\mathrm{ml}^{-1}$. The second technique was a test for presence/absence of the phage performed on samples of 50 to $100 \mathrm{ml}$ when it was expected that concentrations would be very low. The water sample was subjected to ultra-filtration and the filter medium was backwashed to provide a small volume of water into which any phage present had been concentrated. This was used to treat the plate culture of the host bacterium and if 
lysis occurs the test indicates that the bacteriophage was present in the water sample. If there is no lysis then the result is negative.

A third bacteriophage, Phix 174, was employed to test the sinking stream at Smithcroft Copse, alongside four dye tracers used simultaneously (Maurice, 2009). Similar methods were used but as concentrations of Phix 174 were mostly very high, the analyses were all made on $0.1 \mathrm{ml}$ or $1 \mathrm{ml}$ samples.

Bacteriophage monitoring continued for 14 days following tracer injections except for during the Smithcroft Copse test in which monitoring only continued for 10 days. Concentrations were at or close to background concentrations when monitoring stopped.

\section{Tracer tests and results}

\subsection{Miram's Copse stream sink}

As described above, Photine CU injected into Miram's Copse stream was never detected. Bacteriophage was employed (under similar hydrological conditions) to

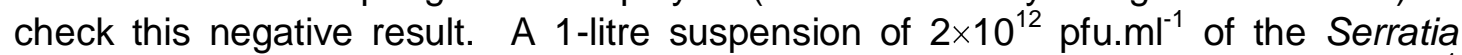
marcescens phage was injected into the stream, which was running at about $3 \mathrm{I}^{-\mathrm{S}^{-1}}$ on 15 February 2006 . It was rapidly washed into the subsurface.

Background samples had been taken from the three sites shown in Fig.1 on ten occasions during the three weeks before injection and analysed using the presence/absence method. In the River Thames and at some sites in the River Pang there were positive results in some of the background samples. These were reanalysed using $1 \mathrm{ml}$ volumes and gave maximum concentrations of $1 \mathrm{pfu} . \mathrm{ml}^{-1}$, with many samples that had proved positive in the $50 \mathrm{ml}$ presence/absence test turning out to be negative in the less sensitive $1 \mathrm{ml}$ test. It was concluded that a background of Serratia marcescens phage was present in both the Thames and Pang rivers, so subsequent samples from these sites were analysed using $1 \mathrm{ml}$ of sample, because positives from the presence/absence technique could not be distinguished from background.

Bacteriophage from Miram's Copse was conclusively detected at the Blue Pool using the presence/absence method (Fig.3). Serratia marcescens phage was not detected at concentrations significantly above background at any other site. Maurice (2009) gives details. At the Blue Pool, tracer was present in 13 samples covering 9 to 102 hours after injection. Re-analysis using $1 \mathrm{ml}$ of water failed to show any phage, indicating that concentrations were $<<1 \mathrm{pfu} . \mathrm{ml}^{-1}$. This interpretation is confirmed by the fact that many of the samples taken during the four days following injection proved negative by the presence/absence method. The average concentration of phage was therefore close to the detection threshold of $<1$ pfu per $100 \mathrm{ml}$. This result is consistent with the previous failure of Photine $\mathrm{CU}$, because the concentration of phage was reduced by a factor of at least $10^{12}$ and Photine CU would be undetectable at such great dilution. The very large attenuation was combined with rapid transport, with first detection of phage after 9 hours at a distance of $1.6 \mathrm{~km}$ from the injection point indicating a velocity of $4.3 \mathrm{~km} \cdot \mathrm{d}^{-1}$.

\subsection{Smithcroft Copse stream sink}

Bacteriophage Phix 174 and four dye tracers were injected simultaneously at Smithcroft Copse on 26 February 2006. This test is fully described by Maurice (2009) and only an outline is given here, pending fuller discussion in a future publication. Three of the dyes including fluorescein confirmed the previous tests reported by Maurice et al. (2006), i.e. recoveries of 21 to $25 \%$ at the Blue Pool (Table 2 ). The fourth dye was slightly retarded, probably reflecting sorption. Bacteriophage 
Phix 174 had a similar shaped breakthrough curve to the three dyes but attenuation was much greater and total recovery only $0.87 \%$ of the amount injected, a difference that may be due to irreversible sorption and die-off. Nevertheless the peak concentration was $1140 \mathrm{pfu}^{-1} \mathrm{ml}^{-1}$ which is much greater than the extremely low concentrations of $\ll 1$ pfu. $\mathrm{ml}^{-1}$ detected from Miram's Copse, and represents a much lower degree of attenuation. The transport of all tracers was very rapid, with velocities of 4.7 to $5.1 \mathrm{~km}$ per day based on time-to-peak over a straight-line distance of $5.1 \mathrm{~km}$. Thus, this pathway is characterised by a combination of rapid groundwater flow with moderate attenuation of dyes and an attenuation of phage that is appreciable but several orders of magnitude less than for the other flow paths tested (Table 2).

\subsection{Frilsham stream sink}

A 1 -litre suspension containing $2 \times 10^{12} \mathrm{pfu}^{\mathrm{ml}} \mathrm{l}^{-1}$ of Enterobacter cloacae bacteriophage was injected into Frilsham sinking stream on 15 February 2006, when

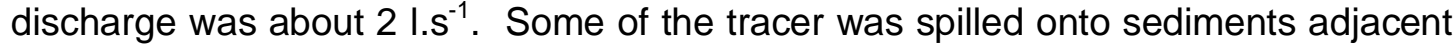
to the stream and this was sluiced back using a bucket and 50 to 100 litres of stream water. Monitoring sites and sampling were the same as for the bacteriophage injection at Miram's Copse (Fig.1). During background monitoring of the Blue Pool, the Enterobacter cloacae phage was absent using the presence/absence method. It was also absent in 40 samples taken during a period of 19 days in 2005 . The samples taken following injection at Blue Pool were therefore analysed using the presence/absence method. On the other hand, the concentrations of Enterobacter cloacae in background samples from the River Pang and River Thames showed sporadic positive results using both presence/absence and $1 \mathrm{ml}$ methods for analysis. Therefore the $1 \mathrm{ml}$ method was used for the Thames and the Pang because presence/absence could not have revealed any difference from background.

The results for all 120 samples from the Blue Pool following injection at Frilsham were negative. All samples from the River Pang were also negative. In the River Thames concentrations of 1 pfu. $\mathrm{ml}^{-1}$ occurred in two samples, but this is not above background. Thus, the tracer from Frilsham sinking stream has not been detected at any monitored site. Frilsham's position between the proven flow paths from Miram's Copse and Smithcroft Copse (Fig.1) make it highly likely that the water from this site does in fact contribute to the Blue Pool. The reason for the negative result may be that the velocity of flow was too slow for the tracer to have emerged during the monitoring period, or that there was an even greater attenuation of tracer concentration than was observed for Miram's Copse.

\subsection{Cromwells stream sink}

Serratia marcescens phage $\left(2 \times 10^{12}\right.$ pfu. $\left.\mathrm{ml}^{-1}\right)$ was injected in Cromwells Stream Sink on 14 March 2005. The stream was flowing at about $2 \mathrm{I} . \mathrm{s}^{-1}$ and formed a small pond where it drained through fine sediments into the Chalk. The tracer was monitored at Bagnor and Jannaways springs, in the Winterbourne stream immediately upstream of the springs, in the River Lambourn, in abstraction boreholes at Speen, and at the Blue Pool (Fig.2). Positive results were obtained by the presence/absence method at Bagnor Spring in nine samples taken between 2 and 13 days after injection (Fig.4). Although many other samples taken in the same period were negative, background monitoring had failed to detect any phage, and it is concluded that the results prove groundwater flow with very high attenuation from Cromwells Sink to Bagnor Spring. Velocity based on first detection was $0.64 \mathrm{~km} \cdot \mathrm{d}^{-1}$.

Negative results were obtained at all other sites except for detection of Serratia marcescens phage by the presence/absence method in a single sample at Jannaways spring, 9 days after injection, and in three samples from the River 
Lambourn between 9 and 13 days. The phages found in the Lambourn could have been tracer from Cromwells that had emerged at Bagnor Springs and been carried downstream. However the background monitoring in the Lambourn used the $0.1 \mathrm{ml}$ method, i.e. the least sensitive technique, whereas the positive results were obtained by a method that is $~ 1000$ times more sensitive. In view of the fact that background levels of up to 1 pfu. $\mathrm{ml}^{-1}$ were present in the Thames and Pang rivers, it is possible that the positive results in the Lambourn also reflect a background presence. The single positive sample from Jannaways suggests that a very small proportion of tracer from Cromwells may have emerged at this spring, which is very close to Bagnor. Background sampling failed to detect any Serratia marcescens at Jannaways using presence/absence, which does support this interpretation, but being based on a single positive analysis it should be treated cautiously unless confirmed by a future test.

\subsection{Honeybottom stream sink}

A trickle of water flowing at about $50 \mathrm{ml} . \mathrm{s}^{-1}$ was disappearing directly into a small hole in the floor of this sink when $2 \times 10^{12} \mathrm{pfu}^{-\mathrm{ml}^{-1}}$ of Enterobacter cloacae phage was injected on 14 March 2005. Monitoring was the same as for Cromwells Sink (Fig.2) but no tracer was detected at any site. Because Honeybottom and Cromwells Sinks are close to one another it seems likely that groundwater from both emerges at Bagnor springs and that the Honeybottom tracer was so attenuated along its flowpath that it could not be detected with the monitoring and analysis techniques used. There was very little flow entering the ground during this tracer test and it is possible that this caused greater attenuation and dilution than during other tracer tests.

\section{Discussion}

\subsection{Catchment area of the Blue Pool spring}

The discharge of the Blue Pool is known only from 15 spot measurements between 1976 and 1988 (David Banks, personal communication 2007) plus the measurements made during our tracer tests in 2004-6. The mean discharge is $\sim 0.2$ $\mathrm{m}^{3} . \mathrm{s}^{-1}$ and the range of measurements 0.15 to $0.24 \mathrm{~m}^{3} . \mathrm{s}^{-1}$. Water tracing has proved that the sinking streams at Smithcroft Copse and Miram's Copse both contribute to the spring. Its catchment area must include the area between these two sites. A box drawn around these sites encloses an area of $7 \mathrm{~km}^{2}$ (Fig. 5). If this were the only catchment then a recharge rate of $900 \mathrm{~mm} /$ year would be required to sustain the flow of the spring. This is larger than the mean annual rainfall onto the Pang catchment (692 mm/year for 1968-1997, Wheater et al. 2006), and therefore the catchment area must be much larger. One method of estimating the additional area is to use groundwater contours, sketching curved lines that pass through the Miram's Copse and Smithcroft Copse sinks and are also orthogonal to the groundwater contours. The lines shown on Fig. 5 have been generalised to take account of seasonal changes in the contour pattern. They enclose an area of $58 \mathrm{~km}^{2}$, which would require an annual recharge of about $110 \mathrm{~mm} / \mathrm{year}$ to sustain the flow of the Blue Pool. Finch (2001) estimated the mean recharge for 1972-1997 as $105 \mathrm{~mm} / \mathrm{year}$ which suggests that this area may be roughly correct. However the enclosure on Fig. 5 includes other groundwater outlets, namely the River Pang itself and the line of smaller springs that discharge into it over a $2 \mathrm{~km}$ reach upstream of the Blue Pool (Fig.1). The two largest, Ingle and Jewells springs, had a combined flow of $\sim 0.05$ $\mathrm{m}^{3} . \mathrm{s}^{-1}$ during February 2005 when the Blue Pool discharge was close to average. At that time the flow from the river upstream of the whole group of springs was about $0.09 \mathrm{~m}^{3} . \mathrm{s}^{-1}$ (Table 3 in Maurice et al. 2006), with most of this derived from the channel within the Blue Pool catchment area depicted on Fig. 5 (Griffiths et al., 2006). Thus the total groundwater outflow from this area was about $0.34 \mathrm{~m}^{3} . \mathrm{s}^{-1}$ in February 2005 . This figure is unlikely to represent the annual average flow, because 
it applies to a short period in winter, but if it were it would require annual recharge of $185 \mathrm{~mm} /$ year on a contributing area of $58 \mathrm{~km}^{2}$. This figure is slightly greater than the difference of about $170 \mathrm{~mm} / \mathrm{year}$ between mean annual rainfall $(692 \mathrm{~mm})$ and mean potential evapo-transpiration (520 mm/year for 1969-1975 (Morel, 1980), or 525 $\mathrm{mm} /$ year given without attribution by Wheater et al., 2006), which is a crude estimate of hydrological surplus available for recharge. The rough agreement between these estimates again suggests that the catchment area is approximately correct. We conclude that the Blue Pool and the other springs derive their water from infiltration into the aquifer within roughly the area shown in Fig. 5. The rapid flow-paths that have been traced from the Smithcroft Copse, Tyler's Lane and Holly Lane swallets form the southern boundary of this area. They are aligned aslant the groundwater contours, which suggests that they are part of a zone of anisotropic high permeability that acts as a collector for diffuse groundwater flow from the north-west, and diverts it along enlarged fractures or karst conduits.

\subsection{Groundwater velocity and tracer attenuation - experimental results}

The successful tracer experiments show rapid groundwater flow with velocities $\sim 1$ $\mathrm{km} . \mathrm{d}^{-1}$ that are comparable with previous tests from stream sinks in the Chalk (Table 1 ), and with the conduit velocities observed in karst aquifers (e.g. $0.52-21.2 \mathrm{~km} . \mathrm{d}^{-1}$ among 48 tests in the Carboniferous Limestone of Somerset (Atkinson, 1977); and an average of $1.7 \mathrm{~km}^{-1}{ }^{-1}$ in a wider sample of karst aquifers (Smart \& Worthington, 2004).

Considering attenuation, there are important differences between dyes and bacteriophage tracers (Table 2). The quantitative mass balance for Smithcroft Copse showed moderate attenuation of dye, with around $75 \%$ of tracer remaining undetected, whereas attenuation of Phix 174 bacteriophage was much higher, with 99\% undetected. Nevertheless, the differences in attenuation between sites are much greater than those between the two types of tracers. In contrast to Smithcroft Copse the pathway from Miram's Copse to Blue Pool showed complete loss of dye tracer. Bacteriophages also showed a large difference, with $\sim 1 \%$ of phage being recovered for Smithcroft Copse, but less than $0.00005 \%$ for Miram's Copse. Details of the stream sink and spring elevations, and the unsaturated zone thicknesses beneath the stream sinks are listed in Table 4, which shows that the unsaturated zone beneath Smithcroft Copse stream sink is thinner than that beneath the other stream sinks.

The general picture to emerge from this study is that the velocity of groundwater flow from sinking streams to springs is generally high, but that attenuation of tracers is very variable. Bacteriophages suffered complete attenuation along some groundwater pathways recharged by sinking streams, even where circumstantial evidence suggests that the water flows to a large spring (Frilsham and Honeybottom, Table 2). Other sites with proven connections to springs showed rapid groundwater flow combined with extremely high attenuation of dye and/or phages (Miram's Copse and Cromwell's Sink). Smithcroft Copse, showed rapid flow combined with moderate dye attenuation (Table 2). All these tracer tests were carried out in winter when groundwater levels are high and the stream sinks are flowing. It is likely that under these conditions groundwater flow may be more rapid than under low water table conditions and therefore attenuation due to dispersion and diffusion will be less. The wide range of attenuation in the Pang and Lambourn area suggests that the previous tests listed in Table 1 may be a biased sample of sinking stream behaviour, in that they all show low-to-moderate attenuation. In this they are similar to more clearly karstic aquifers than the Chalk, such as the Carboniferous Limestone, in which attenuation in conduit flows ranges from negligible to moderate (Atkinson et al. 1973; Atkinson, 1977; Stanton \& Smart, 1981). The pathways followed by sinking streams 
through chalk can now be seen to combine rapid flow with a much wider range of attenuation than observed in simple conduits. Any attempt to provide a full description of these rapid flow paths and their relationship to the general structure of voids in the Chalk aquifer must take account of this.

\subsection{Groundwater velocity, tracer attenuation and void apertures}

The speed of groundwater flow and the rate of tracer attenuation are both strongly affected by the apertures of voids along each flow path in an aquifer. Other factors being equal, flow velocity within a single planar void increases with the square of its aperture. As shown by Price (1987) 'secondary' fractures with apertures $\sim 0.01 \mathrm{~m}$ can account for observed groundwater flow speeds of several $\mathrm{km}$ per day, provided this aperture is maintained along the entire pathway. Primary fractures are over ten times smaller and so can be expected to give rise to flow speeds of tens of metres per day, or less. Tracer attenuation occurs by a variety of mechanisms in the Chalk, each dependent in some way on aperture. Classical hydrodynamic dispersion depends on the differences in velocity among different parts of a fracture, which are strongly influenced by the variability of its aperture. Hydrodynamic dispersion is also produced where tracer is transported through a network of fractures and fissures in which there are differences in average velocity among many possible pathways through the network. A potentially more powerful attenuating mechanism is diffusion of tracer molecules from regions of high concentration in fractures into regions of low (initially zero) concentration within the pore space of the adjacent rock matrix. The rate at which this mechanism (termed Double Porosity Diffusion) can reduce the concentration of tracer within the fracture is inversely proportional to the square of the aperture (Barker, 1991). The degree of attenuation that can be produced depends on the speed with which the tracer is advected along the fracture, and this also depends on the square of the aperture. In combination, these two effects cause attenuation by Double Porosity Diffusion to vary inversely with the third power of the aperture, assuming a constant width and hydraulic gradient. Thus reducing aperture by ten times would increase attenuation by one thousand times. The net effect of aperture on flow and attenuation is that in relatively large voids flow speeds are rapid and attenuation relatively low and dominated by hydrodynamic dispersion, whereas in small voids flow speeds are low and attenuation is high and dominated by Double Porosity Diffusion.

Somewhat similar effects operate in the case of particulate tracers such as bacteriophages. For these the principal attenuation mechanism is irreversible sorption on fracture walls and/or trapping in the pore spaces of the matrix. The likelihood of a particle colliding with the wall of a fracture depends on its surface-tovolume ratio and is inversely proportional to its aperture. Thus, the attenuation of phage tracers will be more effective during transport through narrow voids.

\subsection{Conceptual models of karstic channels in the Chalk aquifer}

Applying the principles just outlined to the tracer test results suggests the conceptual model of groundwater pathways shown in Fig. 6 . The high transport velocities for the recovered portions of the tracers indicates that some flow must have been in voids with apertures of $\sim 0.01 \mathrm{~m}$ or more, i.e. fractures that have been widened by solution to form fissures or small conduits. Detection of tracer at a spring indicates that a large-aperture pathway must extend over most or all of the distance from the injection point. On the other hand, high attenuation suggests that much of the flow took place along narrow voids, where diffusion into the matrix would reduce dye concentrations to low levels and sorption on walls or in pores of the matrix could attenuate the concentrations of bacteriophage. These contradictions are resolved by a network topology in which conduits and enlarged fractures form a radial divergent pattern of distributaries around sinking steams, and a convergent pattern close to 
springs. Three such networks are illustrated in Fig. 6, which shows enlarged voids (conduits and enlarged fractures) as lines but does not illustrate the network of primary fractures that occurs throughout the volume of the aquifer. Flow through this network of narrow fractures is implied to occur in the blank parts of the diagrams in Fig. 6. The first panel of Fig. 6 shows a situation in which the only pathway by which water may flow between the network around the sinking steam and the network near the spring is through narrow primary fractures. This type of system will result in complete loss of tracer. Recharge entering the stream sink will divide among the radial divergent enlarged pathways and distribute the tracer into the network of narrow, primary fractures, where complete attenuation can occur. We suggest that the tracers injected into Frilsham and Honeybottom sinks may have encountered situations of this type.

The second panel in Fig. 6 shows a situation in which a single enlarged pathway links the network around the sinking stream with the network around the spring. In this situation most of the tracer injected into the sink will be carried into the primary fracture network, but a small proportion will travel rapidly to the spring along the connecting enlarged pathway. An observer at the spring will perceive rapid arrival of the tracer combined with high losses. We envisage that this was the type of network at Cromwell's sink and Miram's Copse, in which dye was undetectable and there was extremely high attenuation of bacteriophage.

In the last panel of Fig. 6 there are multiple connections via enlarged voids between the sinking stream and the spring, and their respective networks are integrated. In this situation, some of the tracer injected into the sink would still be carried into the primary fractures and lost by double porosity diffusion or sorption, but much would remain within the network of enlarged voids. The rapid flow and low attenuation in these would result in much higher recoveries of tracer at the spring. This model corresponds to the results obtained at Smithcroft Copse, and to most of the previous tracer experiments in chalk listed in Table 1.

A possible objection to this interpretation is that such a variety of different tracers have been used in the Pang and Lambourn experiments that the results may reflect differences in tracer properties rather than variation in the structure of permeable voids from one sinking stream to another. This seems unlikely in view of reported results from experiments in which different tracers were used alongside one another. Skilton \& Wheeler (1988) used Serratia marcescens and Enterobacter cloacae phages in forced-gradient radial flow tests in the Yorkshire Chalk and found similar recoveries for both. This suggests that it is coincidence that Enterobacter cloacae was used in both of the experiments that showed total loss in the present study. However, Phix 174 phage may be a more conservative tracer than Serratia marcescens or Enterobacter cloacae phages. Goyal \& Gerba (1979) found it one of the least sorbed on soils out of five phages studied, while Schijven \& Hassanizadeh (2000) have noted that it is stable and not hydrophobic. There are no groundwater studies in which Phix 174 has been used alongside Serratia marcescens phage, so it is conceivable that the lower attenuation in the Smithcroft Copse experiment was due to differences between phages. Militating against this is the comparison between Fluorescein dye at Smithcroft Copse and Photine CU at Miram's Copse, which showed very large differences in attenuation between the two pathways, confirming the similar contrasts shown by the phages. Fluorescein and Photine CU have been used simultaneously in a tracer study in Carboniferous Limestone by Smart (1988) and had similar recoveries. Finally, Price et al. (1992) used Photine CU and Serratia marcescens phage in separate experiments along the same flowpath in the Chalk, and obtained similar results. Though there are undoubted differences in the susceptibility of different tracers to losses by sorption and double porosity diffusion, it 
appears that these are likely to be of secondary importance. Attenuation reflects real differences in the structure of conduits and enlarged fractures within the Chalk, as shown in Fig.6.

\subsection{Implications for groundwater protection}

Sinking streams have long been recognised as potential sources of contamination for groundwater in chalk (Prestwich, 1854; Richards \& Brinker, 1908; Whitaker, 1886; Harold, 1937; Atkinson \& Smith, 1974; Edmonds, 2008), because of the ease with which surface waters may be polluted. It has also long been recognised that the passage of water through an aquifer may attenuate many contaminants to the point at which they present little hazard to consumers of the water. This varies with the nature of the aquifer and with the properties of the contaminant. Dilution, sorption and degradation will all attenuate dissolved contaminants whereas filtration, sorption, degradation and die-off mitigate contamination by particulates including microorganisms. Attenuation processes are most effective in granular media, and least effective in the open channels and enlarged fractures found in karst aquifers. In karst aquifers such as the Carboniferous Limestone, stream sinks almost invariably contribute to conduit flow through the aquifer, and contaminants or tracers introduced into them generally reach springs and sometimes boreholes within hours or days, with low attenuation or loss during their underground transit (Atkinson, 1977; Ford \& Williams, 2007). There are therefore strong grounds for supposing that sinking streams in the Chalk might equally invariably feed into karst channels that connect to springs with rapid transport and low attenuation. The results of the tracer tests in this study demonstrate that this is an over-simplification. Certainly rapid flow is associated with sinking streams. Wherever tracer tests have been successful, transport to springs has been at velocities of several km/day. However the Miram's Copse and Cromwell's tests show that rapid flow can be combined with extremely high attenuation of both solute and bacteriophage tracers. This finding may explain a paradox that has previously escaped comment in groundwater literature, namely that even in chalk districts containing sinking streams and other surface karst features serious pollution of groundwater sources has historically been comparatively rare. Most contamination at borehole sources consists of sporadic appearances of suspended sediment and faecal bacteria at low concentrations (MacDonald et al., 1998). Springs draining areas containing stream sinks may show more frequent contamination, as they are likely to be directly fed from one or more stream sinks via a rapid flow channel. However, much of the recharge from stream sinks is likely to be dispersed into the wider aquifer and to form a low proportion of water pumped from boreholes for water supplies. If a pumped borehole intersects an enlarged fracture that is part of the radial network around a stream sink (Fig. 6) then it may be affected by sporadic contamination. This is likely to be diluted within the borehole by water from uncontaminated parts of the aquifer. To reach a borehole that does not intersect any part of the enlarged fracture networks fed directly by sinking streams, contamination from a stream sink would have to pass through the primary fracture network over part of its pathway, where greater attenuation is likely to occur.

It is clear that when assessing risks of contamination to groundwater sources, proximity to sinking streams is a factor indicating high risk (Edmonds, 2008). However the tracer experiments show that contamination from stream sinks may be attenuated before reaching boreholes, depending on the degree to which the karst channel and enlarged fracture network is developed beneath the sink (as shown in Fig. 6), and on whether the borehole intersects this network directly, or is fed from it indirectly via the primary fracture network. 


\section{Conclusions}

New tracer tests on sinking streams in the Chalk in the Pang and Lambourn catchments of southern England have confirmed the existence of rapid groundwater flow. In most sinking streams tested up to the present time this rapid flow has been combined with relatively low attenuation of tracers, producing well-defined breakthrough curves and/or high concentrations of tracer at springs. However some of the new tests show that rapid flow may also be combined with very high levels of attenuation. As tracer testing was carried out from the most well developed stream sinks with the highest flows it is possible that only a small proportion of all stream sinks are connected to groundwater outlets with rapid velocities combined with low attenuation, even though the large numbers of stream sinks along Chalk-Palaeogene margins are collectively important in terms of recharge.

The range of attenuation seen in tracer results implies that networks of karst cavities are unevenly developed within the Chalk aquifer. A three-state model is proposed (Fig. 6). The networks beneath stream sinks distribute recharge into multiple enlarged fractures that divide and become smaller at each division whereas the networks around springs have a predominantly tributary topology that concentrates flow into a few relatively large cavities, a morphology with similarities to that of the early stages of karstification proposed by Ford and Williams (1989; 2007) and modelled by Dreybodt et al. (2005). Tracer attenuation is controlled by the degree to which the two networks are directly connected. In the first state, there is no direct linkage and flow between the two networks is via primary fractures in which tracer attenuation is extreme. The second state is a a percolation threshold in which a single direct link joins the two networks. A very small proportion of tracer reaches the spring rapidly but overall attenuation is very high or extreme. In the third state, the recharge and discharge networks are integrated therefore a large fraction of tracer reaches the spring and peak concentrations are relatively high.

Sinking streams are always an indicator of high intrinsic vulnerability of an aquifer to contamination (Drew \& Hotzl, 1999; Edmonds, 2008). Springs are generally more likely to be vulnerable than boreholes. Pumping boreholes that directly intersect the enlarged fracture network around a stream sink are highly vulnerable, but if there is no direct connection then contaminants may be attenuated to some extent as they pass through primary fractures along a part of their route.

Edmonds (2008) has recently emphasized the importance of karst features in mapping groundwater vulnerability in the Chalk, and recommends that groundwater protection zones should be defined to take account of the possibility of rapid flow of contaminants from stream sinks and dolines. The present study demonstrates that tracer tests using bacteriophage which can be injected at high concentrations $\left(10^{12}\right.$ pfu. $\mathrm{ml}^{-1}$ ) are an effective method of investigating rapid flow while directly indicating the degree of attenuation experienced by micro-organisms in transport through the aquifer.

\section{Acknowledgements}

This work was funded by Natural Environment Research Council grant $\mathrm{NER} / \mathrm{T} / \mathrm{S} / 2001 / 00956$. We thank the landowners in the catchments for allowing access. This paper is published with the permission of the Executive Director, British Geological Survey (NERC). 


\section{References}

Atkinson, T.C., Smith, D.I., Lavis, J.J., and Whitaker, R.J., 1973. Experiments in tracing underground waters in limestones. Journal of Hydrology 19, 323-349

Atkinson, T.C. and Smith D.I., 1974. Rapid groundwater flow in fissures in the Chalk: An example from South Hampshire. Quarterly Journal of Engineering Geology 7, 197-205

Atkinson, T.C., 1977. Diffuse flow and conduit flow in limestone terrain in the Mendip Hills, Somerset (Great Britain). Journal of Hydrology 35, 93-110

Banks, D., Davies, C., and Davies,W., 1995. The Chalk as a karstic aquifer: evidence from a tracer test at Stanford Dingley, Berkshire, UK. Quarterly Journal of Engineering Geology 28, S31-S38

Barker, J.A., 1991. Transport in fractured rock. In Applied Groundwater Hydrology. Edited by Downing, R.A., and Wilkinson, W.B. Oxford University Press. 199-216

Barnes, S. 1999. Karstic groundwater flow characteristics in the Cretaceous Chalk aquifer, Northern Ireland Quarterly Journal of Engineering Geology 32, 55-68.

Bradshaw J., Caiger N., Halpin M., Le Gear R., Pearce A., Pearman H., Reeve T. and Sowan P., 1991. Kent and East Sussex Underground. Kent Underground Research Group. Meresborough Books. 128 pp.

Codrington, T. 1864. The geology of the Berks \& Hants extension, and Marlborough Railways. Wiltshire Archaeological and Natural History Magazine 9, 167-193.

Drew, D. \& Hotzl, H. (eds), 1999. Karst Hydrogeology and Human Activities. Impacts, Consequences and Implications, International Contributions to Hydrogeology vol. 20, A.A. Balkema, Rotterdam 322 pp.

Dreybrodt, W., Gabrovšek, F., and Romanov, D., 2005. Processes of speleogenesis: A modelling approach. ZRC publishing, Karst Research Institute at ZRC SAZU. 375 $\mathrm{pp}$

Edmonds, C., 2008. Improved groundwater vulnerability mapping for the karstic chalk aquifer of south east England. Engineering Geology 99, 95-108

Farrant, A. R. 2001. Karst development in the Southern English Chalk. In: Beck, B \& Herring, G. (eds). Geotechnical and Environmental Applications of Karst Geology and Hydrology. Proceedings of the 8th Multidisciplinary conference on Sinkholes and the Engineering and Environmental Impacts of Karst. Louisville, Kentucky. Balkema. Lisse, 77-82.

Finch, J.W., 2001. Estimating change in direct groundwater recharge using a spatially distributed soil water balance model. Quarterly Journal of Engineering Geology and Hydrogeology 34, 71-83

Ford, D.C., and Williams, 1989. Karst geomorphology and hydrology. London, Unwin Hyman. $601 \mathrm{pp}$

Ford, D.C., and Williams, 2007. Karst hydrogeology and geomorphology. John Wiley and Sons Ltd. $562 \mathrm{pp}$ 
Foster, S.S.D., 2000. Assessing and controlling the Impacts of Agriculture on Groundwater - from Barley Barons to Beef Bans. Quarterly Journal of Engineering Geology and Hydrogeology 33 (4), 263-280

Goyal, S.M., and Gerba, C.P., 1979. Comparative adsorption of human enteroviruses, Simian Rotavirus, and selected bacteriophages to soils. Applied and Environmental Microbiology 38 (2), 241-247

Griffiths J., Binley, A., Crook, N., Nutter, J., Young, A., and Fletcher, S., 2006. Streamflow generation in the Pang and Lambourn catchments, Berkshire, UK. Journal of Hydrology 330 (1-2) Special Issue "Hydro-ecological functioning of the Pang and Lambourn catchments, UK - Results from the Lowland Catchment Research (LOCAR) initiative" edited by Wheater. 71-83

Harold C., 1937. The flow and bacteriology of underground water in the Lee Valley. Metropolitan Water Board 32nd Annual Report, 89-99.

Käss, W., 1998. Tracing technique in Geohydrology. Rotterdam, Netherlands: A.A. Balkema. $581 \mathrm{pp}$

Lamont-Black, J., and Mortimore, R., 1999. Predicting the distribution of dissolution pipes in the Chalk of southern England using high resolution stratigraphy and geomorphological domain characterisation. Hydrogeology and Engineering Geology of Sinkholes and Karst: Proceedings of the Seventh Multidisciplinary Conference on Sinkholes and the Engineering and Environmental Impacts of Karst. Balkema, Rotterdam 97-102

Long, G., 1842. On the occurrence of numerous swallow holes near Farnham.

Proceedings of the Geological Society of London III (1838-42), 101-102

Lowe, D.J., 1992. Chalk caves revisited. Cave Science, Transactions of the British Cave Research Association 19, 55-58

MacDonald A.M., Brewerton L. and Allen D.J., 1998. Evidence for rapid groundwater flow and karst type behaviour in the Chalk of Southern England. In: Groundwater pollution, aquifer recharge and vulnerability, Robins NS (Ed), Geological Society of London special publication No. 130, 95-106.

Massei, N., Lacroix, M., Wang, H.Q., Mahler, B.J., and Dupont, J.P., 2002. Transport of suspended solids from a karstic to an alluvial aquifer: the role of the karst/alluvium interface. Journal of Hydrology 260, 88-101

Massei , N., Wang, H.Q., Field, M.S., Dupont, J.P., and Rodet, J., 2006. Interpreting tracer breakthrough tailing in a conduit-dominated karstic aquifer. Hydrogeology Journal 14 (6), 1431-2174

Maurice, L., 2009. Investigations of rapid groundwater flow and karst in the Chalk. Unpublished PhD thesis, University College London.

Maurice, L., Atkinson, T.A., Barker, J.A., Bloomfield, J.P., Farrant, A.R., and Williams, A.T., 2006. Karstic behaviour of groundwater in the English Chalk. Journal of Hydrology 330 Special Issue "Hydro-ecological functioning of the Pang and Lambourn catchments, UK - Results from the Lowland Catchment Research (LOCAR) initiative" edited by Wheater. 53-62. 
Morel, E.H., 1980. The use of a numerical model in the management of the Chalk aquifer in the Upper Thames Basin. Quarterly Journal of Engineering Geology 13, 153-165

Prestwich, J., 1854: On the structure of the strata between the London Clay and the Chalk in the London and Hampshire Tertiary systems. 2 The Woolwich and Reading series. Q.J. geol. Soc. Lond. 10, 75-170.

Price, M., 1987. Fluid flow in the Chalk of England. Geological Society Special Publication 34, 141-156

Price M., Atkinson T.C., Barker J.A., Wheeler D and Monkhouse R.A., 1992. A tracer study of the danger posed to a chalk aquifer by contaminated highway run-off. Proceedings of the Institution of Civil Engineers: Water, Maritime, \& Energy 96, 9-18

Procter, C., 1984. Chalk caves in Devon. Caves and Caving 26, 31

Reeve, T.J., 1977. Chalk caves in Sussex. British Cave Research Association Bulletin 18, 3-4

Richards, H.M., and Brinker, J.A.H., 1908. The potential dangers of water derived from wells in the Chalk. Proceedings of the Royal Society of Medicine vol i, Epidemiological Section, 191-203

Rodet, J., 1991. Les Karsts de la Craie. Etude Comparitive. Unpublished PhD thesis. Universite de Paris-Sorbonne.

Rodet J., Willems L., Brown J., Ogier-Halim S., Bourdin M., Viard J.-P. (2009b). Morphodynamic incidences of the trepanning of the endokarst by solution pipes. Examples of chalk caves in Western Europe (France and Belgium). Proceedings of the 15th International Congress of Speleology, Kerrville (Texas, USA), 19-26 july 2009, UIS-NSS, vol. 3, contributed papers : 1657-1661 [isbn 978-1-879961-35-7].

Schijven, J.F. and Hassanizadeh, S.M., 2000. Removal of viruses by soil passage: overview of modelling, processes, and parameters. Critical reviews in Environmental Science and Technology 30 (1), 49-127

Skilton, H. and Wheeler, D., 1988. Bacteriophage tracer experiments in groundwater. Journal of Applied Bacteriology 65, 387-395

Smart, C.C., 1988. Artificial tracing techniques for the determination of the structure of conduit aquifers. Groundwater 26, 445-453

Smart, C.C, and Worthington. S.R.H., 2004. Groundwater in karst. In Encyclopaedia of caves and karst science. Edited by Gunn, J. 394-397.

Smart, P.L., 1976. The use of optical brighteners for water tracing. Transactions British Cave Research Association 3 (2), 62-76

Sperling, C.H. B., Goudie, A.S., Stoddart, D.R., and Poole, G.G., 1977. Dolines of the Dorset chalklands and other areas in southern Britain. Transactions of the Institute of British Geographers 2, 205-223 
Stanton, W.I., and Smart, P.L., 1981. Repeated dye traces of underground streams in the Mendip Hills, Somerset. Proceedings of the University of Bristol Speleological Society 16 (1), 47-58

Warwick, G.T., 1962. British caving regions. Ch 5 in Cullingford, C.H.D., (Ed.). British Caving: An introduction to Speleology. ( $2^{\text {nd }}$ Edition). $592 \mathrm{pp}$

Wheater, H.S., Neal, C., and Peach, D., 2006. Hydro-ecological functioning of the Pang and Lambourn catchments, UK: An Introduction to the special issue. Journal of Hydrology 330 (1-2), 1-10

Whitaker, W., 1886. On recent legal decision of importance in connection with water supplies from wells. Geological Magazine 3, 111-114

Wooldridge, S.W., and Kirkaldy, J.F., 1937. The geology of the Mimms Valley. Proceedings of the Geological Association 28, 31-38

Worthington S.R.H., and Ford., D.C., 2009. Self-organized permeability in carbonate aquifers. Ground Water 47 (3), 326-336 
Figure 1: Tracer testing in the Pang catchment

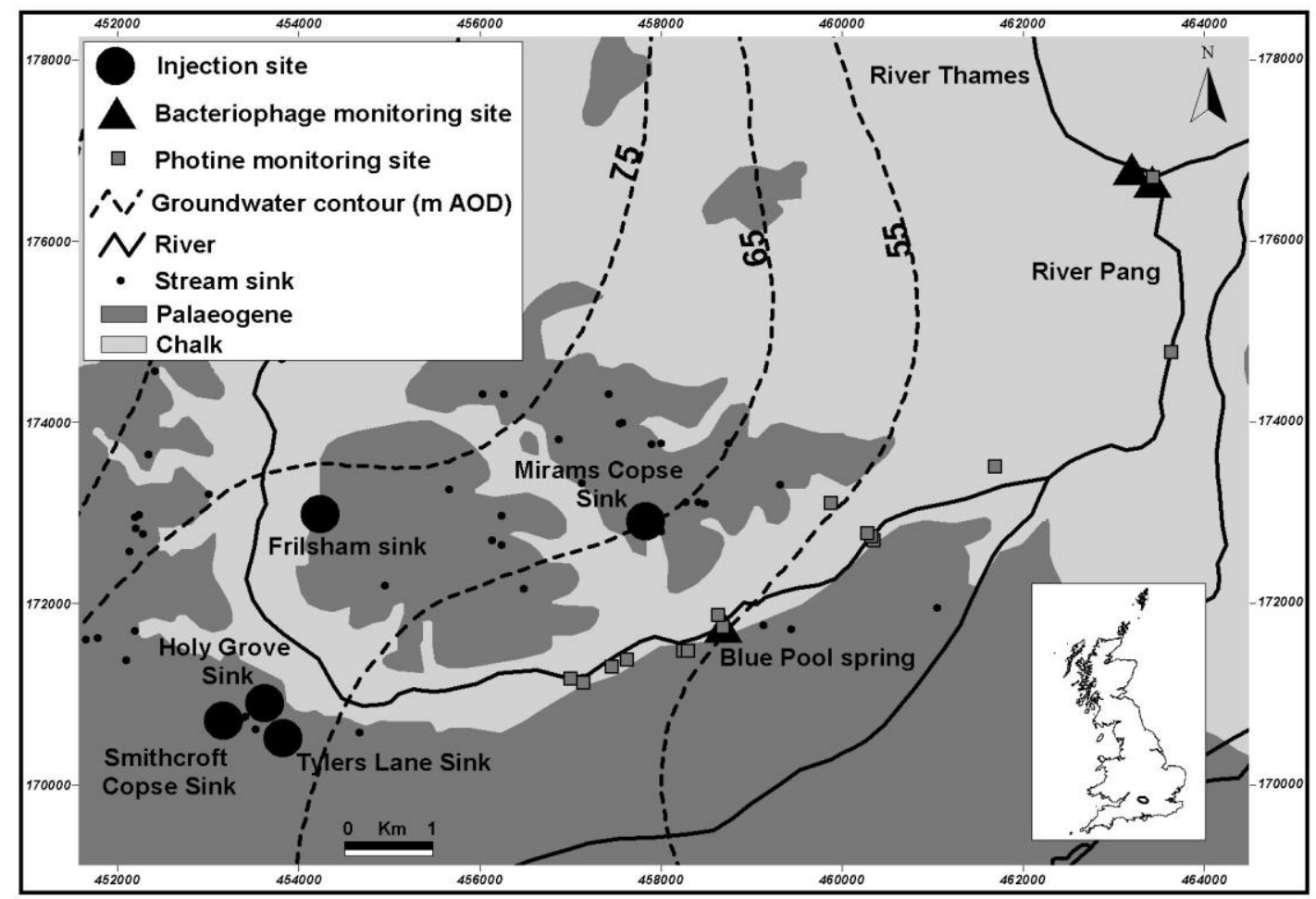


Figure 2: Tracer testing in the Winterbourne catchment

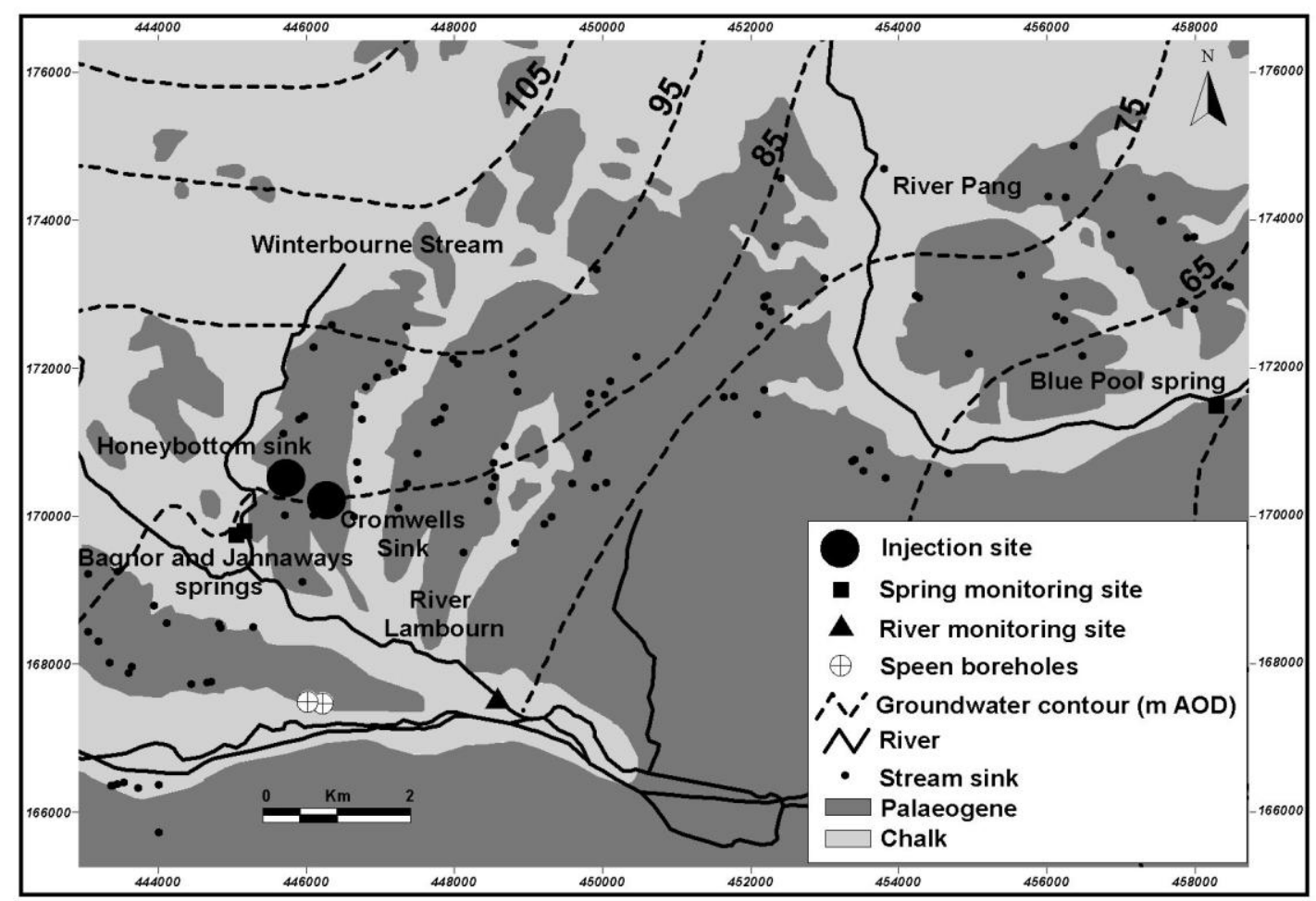


Figure 3: Serratia Marcescens at the Blue Pool spring following injection at Miram's copse stream sink

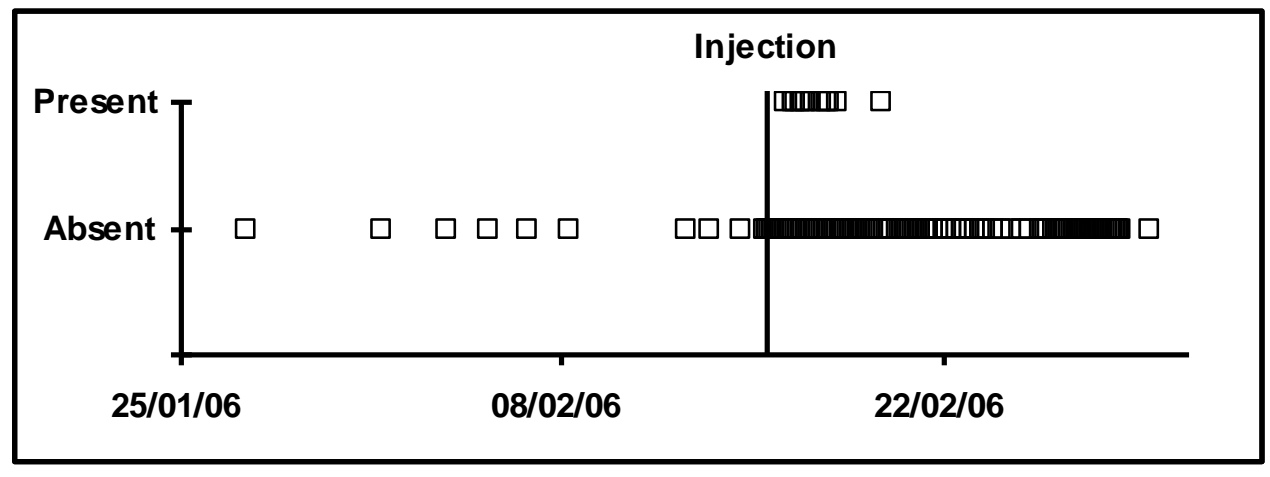


Figure 4: Serratia Marcescens at Bagnor spring following injection at Cromwells stream sink

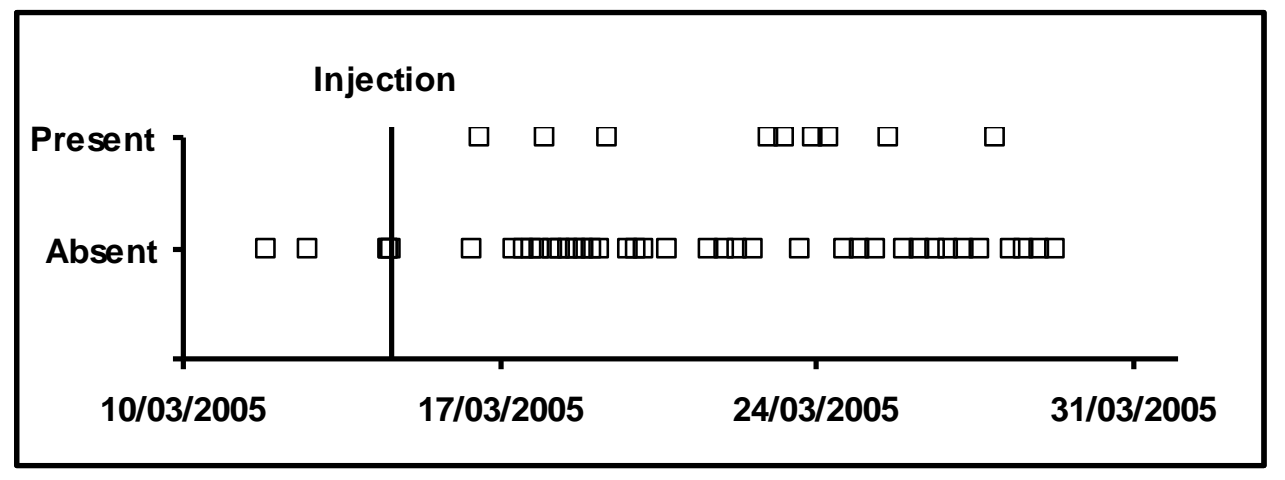


Figure 5: The catchment area of the Blue Pool spring

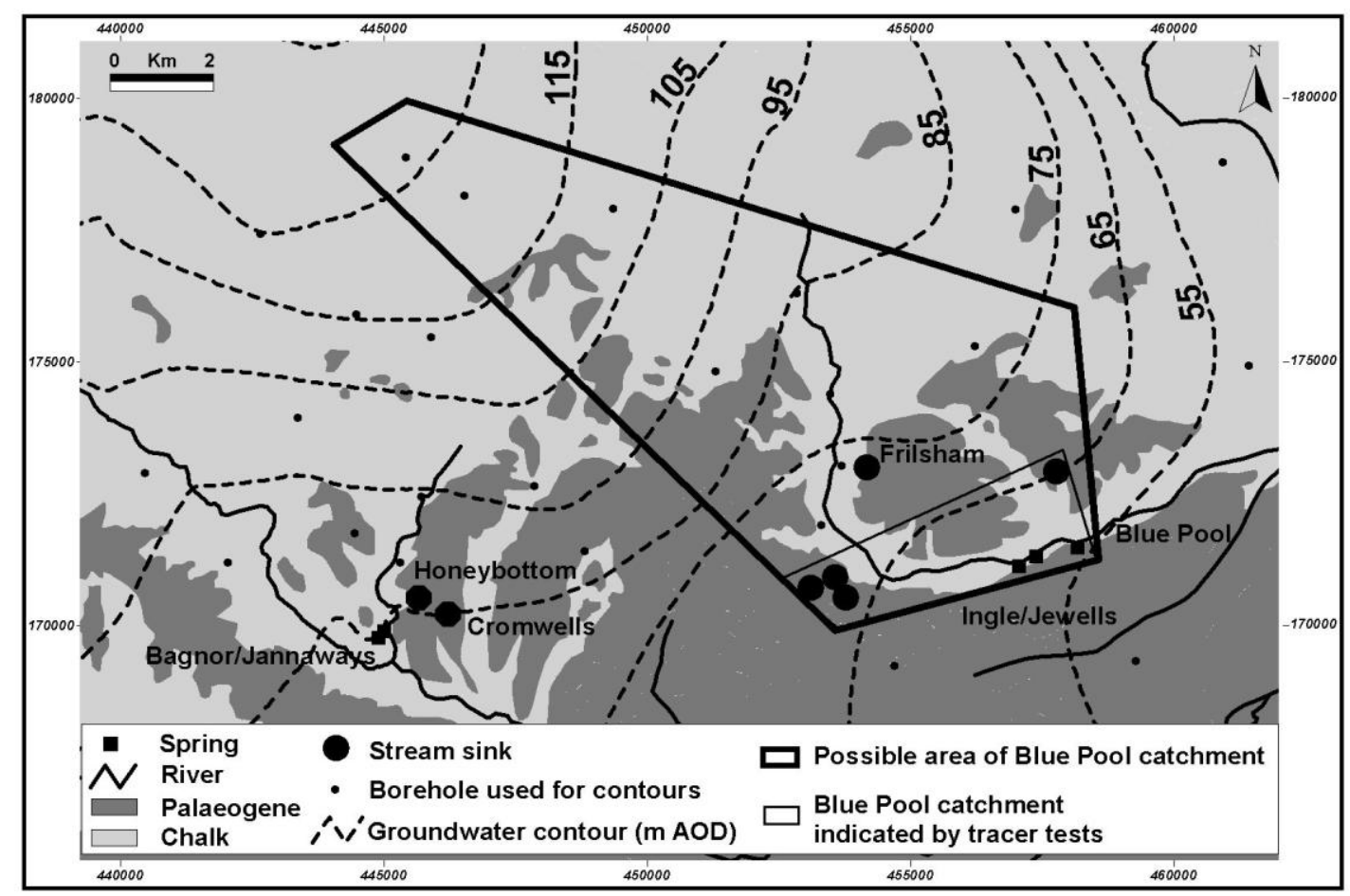


Figure 6: Conceptual model of the nature of groundwater flowpaths between stream sinks and springs indicated by tracer testing

\begin{tabular}{|c|c|}
\hline Stream sink & $\begin{array}{l}\text { Complete tracer loss due } \\
\text { to high attenuation in } \\
\text { fracture/fissure zone } \\
\text { Frilsham Sink, Pang. } \\
\text { Honeybottom Sink, } \\
\text { Lambourn }\end{array}$ \\
\hline Stream sink & $\begin{array}{l}\text { Limited fully connected } \\
\text { conduits with rapid } \\
\text { groundwater flow and } \\
\text { high attenuation } \\
\text { Mirams Copse Sink, Pang. } \\
\text { Cromwells Sink, } \\
\text { Lambourn }\end{array}$ \\
\hline Stream sink & $\begin{array}{l}\text { Fully connected conduits } \\
\text { with rapid groundwater } \\
\text { flow and low attenuation } \\
\text { Smithcroft Copse } \\
\text { Sink, Pang. } \\
\text { Water End, Hertfordshire }\end{array}$ \\
\hline
\end{tabular}


Table 1: Previous tracer tests in chalk

\begin{tabular}{|c|c|c|c|c|}
\hline Location & $\begin{array}{l}\text { Distance } \\
(\mathbf{k m})\end{array}$ & $\begin{array}{l}\text { Velocity } \\
\left(\text { km.d }^{-1}\right)\end{array}$ & Tracer recovery & Author \\
\hline Wiltshire & $1-2$ & - & visible detection & Codrington (1864) \\
\hline Hampshire & 5.8 & $2-2.6^{\mathrm{a}}$ & $70 \%$ & $\begin{array}{c}\text { Atkinson and Smith } \\
\text { (1974) }\end{array}$ \\
\hline Hertfordshire & $8-20$ & $2.7-5.2^{\mathrm{a}}$ & visible detection & Harold (1937) \\
\hline Berkshire & 4.7 & $6.8^{\mathrm{a}}$ & - & Banks et al. (1995) \\
\hline Berkshire & 5.1 & $\begin{array}{l}4.7 \text { to } \\
5.1^{\mathrm{b}}\end{array}$ & 21.7 to $25 \%$ & Maurice et al. (2006) \\
\hline $\mathrm{N}$ Ireland & $0.3-3.6$ & $0.5-2.8^{\mathrm{c}}$ & 52 to $94 \%$ & Barnes (1999) \\
\hline France & $\sim 1.5$ & $1.8-3^{\mathrm{a}}$ & $>90 \%$ & $\begin{array}{l}\text { Massei et al. } \\
(2002,2006)\end{array}$ \\
\hline France & up to 14 & $\sim 4$ & - & Rodet (1991) \\
\hline
\end{tabular}

\footnotetext{
${ }^{a}$ velocity is based on time to first arrival of tracer

${ }^{b}$ velocity is based on time to peak tracer concentration

${ }^{\mathrm{c}}$ velocity is minimum velocity
} 
Table 2: Tracer recoveries in the Pang-Lambourn catchments

\begin{tabular}{ccccc}
\hline Stream sink & Tracer & $\begin{array}{c}\text { Recovery at spring } \\
\text { (\% of injection) }\end{array}$ & $\begin{array}{c}\text { Flow at stream } \\
\left.\text { sink (L.s } \mathbf{s}^{-1}\right)\end{array}$ & $\begin{array}{c}\text { Flow at spring } \\
\left(\mathbf{L . s} \mathbf{s}^{-1}\right)\end{array}$ \\
\hline Smithcroft Copse & Dye & $21-25$ & $\sim 5$ & $\sim 200$ \\
Smithcroft Copse & Phix 174 bacteriophage & 0.87 & $\sim 5$ & $\sim 200$ \\
Miram's Copse & Photine C & 0 & $\sim 0.5-3$ & $\sim 200$ \\
Miram's Copse & Serratia marcescens bacteriophage & $<0.00005$ & $\sim 3$ & $\sim 200$ \\
Cromwells & Serratia marcescens bacteriophage & $<0.000007$ & $\sim 2$ & $\sim 25$ \\
Frilsham & Enterobacter cloacae bacteriophage & 0 & $\sim 2$ & $\sim 200$ \\
Honeybottom & Enterobacter cloacae bacteriophage & 0 & $\sim 0.05$ & $\sim 25$ \\
\hline
\end{tabular}


Table 3: Comparative recoveries of Serratia marcescens and Enterobacter cloacae during three tracer tests in the Yorkshire Chalk (Skilton and Wheeler, 1988)

\begin{tabular}{lcc}
\hline & $\begin{array}{c}\text { \% Recovery of Serratia } \\
\text { marcescens }\end{array}$ & $\begin{array}{c}\text { \% Recovery of Enterobacter } \\
\text { cloacae }\end{array}$ \\
\hline Experiment 1 & 0.49 & 0.12 \\
Experiment 2 & 0.23 & 0.34 \\
Experiment 3 & 0.10 & 0.18 \\
\hline
\end{tabular}


Table 4: Estimated thickness of the unsaturated zone beneath stream sinks

\begin{tabular}{cccccc}
\hline Sink & $\begin{array}{c}\text { Miram's } \\
\text { Copse }\end{array}$ & $\begin{array}{c}\text { Smithcroft } \\
\text { Copse }\end{array}$ & Frilsham & Cromwells & Honeybottom \\
\hline $\begin{array}{c}\text { Sink elevation } \\
\text { (m AOD) }\end{array}$ & 82 & 78 & 89 & 115 & 114 \\
$\begin{array}{c}\text { High water level } \\
\text { at sink (m AOD) }\end{array}$ & 65 & 68 & 72 & 85 & 86 \\
$\begin{array}{c}\text { Low water level } \\
\text { at sink (m AOD) } \\
\text { Unsaturated } \\
\text { zone thickness } \\
(\text { m) }\end{array}$ & 58 & 65 & 69 & 81 & 82 \\
$\begin{array}{c}\text { Spring elevation } \\
\text { (m AOD) }\end{array}$ & $55-60$ & $55-60$ & $55-60$ & $82-85$ & $82-85$ \\
\hline
\end{tabular}

